\title{
The Rate of Growth of Salmonella typhimurium with Individual Carbon Sources Related to Glucose Metabolism or to the Krebs Cycle
}

\author{
By M. H. RICHMOND* AND O. MAALøE \\ University Institute of Microbiology, University of Copenhagen, Øster \\ Farimagsgade $2 A$, Copenhagen $K$, Denmark
}

(Received 12 June 1961)

\begin{abstract}
SUMMARY
Salmonella typhimurium was grown in a number of media containing compounds related either to the tricarboxylic acid (Krebs) cycle or to glucose metabolism. Organisms grown on compounds related to the Krebs cycle are pink when looked at by reflected light, whereas those grown on compounds related to glucose are white. Organisms growing in media containing compounds from one group continue to grow when transferred to media containing another compound of the same group, but not when transferred to media containing a compound from the other group. Growth of organisms in a mixture of one compound from each group leads to the formation of white organisms, i.e. the glucose-like state appears to predominate.
\end{abstract}

\section{INTRODUCTION}

An ealier paper has described the changes occurring in Salmonella typhimurium when organisms growing exponentially in medium 63 containing proline were transferred to medium 63 containing glutamate as sole carbon source, or vice versa (Maaløe \& Richmond, 1961). The experiments reported in the present paper describe the behaviour of the same strain of $S$. typhimurium in shift experiments involving other compounds as sole carbon sources. All the compounds chosen are closely related metabolically to either glucose or the tricarboxylic acid (Krebs) cycle. Organisms growing on compounds related to the Krebs cycle were pink, whereas those grown in compounds related to glucose were white. Further experiments showed that, in general, organisms grown in media containing a compound from one group would continue to grow on transfer to media containing a compound from the same metabolic group, but not when the new medium contained a compound from the other group as sole carbon source. Some preliminary experiments in which bacteria are grown in media containing a mixture of two compounds from different metabolic groups show that the organisms slowly take on the characteristics of the glucose group if incubation in the mixture is continued. The implication of these findings in relation to the enzymic make-up of the organisms is discussed.

* Present address: Bacterial Physiology Division, National Institute for Medical Research, 'The Ridgeway, Mill Hill, London, N.W. 7, England. 


\section{METHODS}

Organisms, media and growth conditions. The strain of Salmonella typhimurium used in these experiments together with the composition of media and details of culture conditions are described in the previous paper (Maaløe \& Richmond, 1961). Escherichia coli (ML 30) was used in certain experiments and was grown in media similar to those used for S. typhimurium.

Chemical compounds. The substrates added to medium 63 as sole carbon sources were all obtained from the California Corporation, Los Angeles, 63, California, U.S.A. The ${ }^{14} \mathrm{C}$-L-proline and the ${ }^{59} \mathrm{FeCl}_{3}$ were obtained from the Radiochemical Centre, Amersham, Buckinghamshire, England. The ${ }^{59} \mathrm{Fe}$ was added to medium 63 to give specific activity in the medium of 3650 c.p.m. $/ \mu \mathrm{g}$. atom. The proline was purified as described previously (Maaløe \& Richmond, 1961) and used at the specific activities indicated in the text.

Membrane filters. Membrane filters (400 $\mathrm{m} \mu$ mean pore diameter) were obtained from the Membranfilter Gesellschaft, Göttingen, Germany. The filters were found to contain considerable quantities of glycerol which contaminated the growth media used to resuspend organisms after filtration. The presence of glycerol was found to shorten the lag period observed in certain experiments in which organisms were transferred from one growth medium to another. In no case was the presence of glycerol found completely to abolish a lag following a change in growth medium.

Estimation of colour of organisms. About $2 \times 10^{10}$ organisms were filtered on to a $\mathbf{2 . 9} \mathrm{cm}$. membrane filter. The filter was removed from the filter holder, stuck to a glass microscope slide and dried at room temperature for at least $4 \mathrm{hr}$. Because of the design of the filter assembly (Roberts et al. 1957) the organisms were deposited in a circular area of about $1.4 \mathrm{~cm}$. diameter in the middle of the filter.

To measure the colour of organisms during the transition from white to pink (or vice versa), filters obtained as described above were compared with a standard curve prepared by filtering a constant number of organisms made of varying proportions of pink and white cells. For normal purposes the standard curve consisted of six filters varying over $20 \%$ steps from $100 \%$ pink bacteria to $100 \%$ white. The experimental filters were then matched to the standard curves by uninitiated people and the average of at least three independent settings plotted. Observers usually agreed on the position of a filter opposite the standard curve within the limits $\pm 15 \%$.

Extraction and estimation of soluble cytochrome components. About $20 \mathrm{ml}$. culture medium containing the equivalent of $0.5 \mathrm{mg}$. dry wt. organisms was precipitated with $80 \mathrm{ml}$. of absolute acetone at $-8^{\circ}$ and the preparation kept at that temperature. After at least $1 \mathrm{hr}$. as much of the supernatant acetone as possible was decanted and the precipitated organisms collected by centrifugation at $-8^{\circ}$. The pellet was washed once with cold acetone, resuspended in $n$-butanol at room temperature, and the organisms treated at $2^{\circ}$ in a Waring blender. After $15 \mathrm{~min}$. the organisms were collected by centrifugation at $-8^{\circ}$ and the butanol layer discarded. Residual traces of butanol were removed by washing (twice) with cold absolute acetone, and the cytochrome extracted from the organisms by treatment for $30 \mathrm{~min}$. with successive $5 \mathrm{ml}$. portions of distilled water at room temperature. The extracts were separated from the organisms by centrifugation and combined. The quantity of 
cytochrome was measured at $416 \mathrm{~m} \mu$ in cuvettes of $5 \mathrm{~cm}$. light path after addition of $10^{-4} \mathrm{M}-\mathrm{Na}_{2} \mathrm{~S}_{2} \mathrm{O}_{4}$ (Tissières, 1956; Richmond \& Kjeldgaard, 1961).

Estimation of ${ }^{59} \mathrm{Fe}$. Samples were prepared for counting as described previously for ${ }^{14} \mathrm{C}$ (Maaløe \& Richmond, 1961). Since ${ }^{59} \mathrm{Fe}$ decays to give $\beta$ particles $(0 \cdot 46 \mathrm{MeV}$ ) and $\gamma$-radiation $(1 \cdot 3 \mathrm{MeV})$, the radioactivity was determined with an end window Geiger-Müller counter in the way described for ${ }^{14} \mathrm{C}$. About $50 \%$ of the $\beta$ particles and about $5 \%$ of the $\gamma$-rays were measured by the equipment used.

\section{RESULTS}

Preliminary experiments showed that Salmonella typhimurium grown in medium 63 containing $\mathrm{Na}$ glutamate or proline as sole carbon source were pink when looked at in bulk by reflected light. Organisms grown on glucose as sole carbon source were white or pale cream under similar conditions. In view of these findings, organisms were grown exponentially in medium 63 (containing $\mathrm{KH}_{2} \mathrm{PO}_{4}, \mathrm{NH}_{4} \mathrm{Cl}, \mathrm{MgSO}_{4}$, $\mathrm{FeCl}_{3}$; see Maaløe \& Richmond, 1961) containing different carbon compounds as sole carbon sources and the colour of the organisms in the exponential phase of growth observed by the filter technique. The colours of the organisms grown on the different carbon compounds are recorded in Table 1. Two clear classes of organisms were obtained. The first (glutamate-grown) were characterized by their pink colour; the second (glucose-grown) were white. It is striking that the compounds related to white bacteria are those closely related metabolically to glucose; those producing pink bacteria are related to the tricarboxylic acid (Krebs) cycle.

\section{Table 1. Colour of Salmonella typhimurium after about $2 \times 10^{10}$ organisms had been collected on a $2.9 \mathrm{~cm}$. membrane filter}

\footnotetext{
The organisms were grown in medium 63 containing the different single substrates sole carbon source

White cells (glucose-like)

Glucose, mannose, maltose, fructose, glycerol, dulcitol, arabinose

\author{
Pink cells \\ (glutamate-like) \\ succinate, fumarate, \\ $\alpha$-ketoglutarate, malate, \\ histidine, proline, alanine
}

Glutamate, pyruvate,
}

Since it could be shown that pink bacteria contain a higher amount of cytochrome than white bacteria (Richmond \& Kjeldgaard, 1961), the incorporation of ${ }^{59} \mathrm{Fe}$ was followed into the trichloroacetic acid (TCA)-insoluble portion of the organisms grown with glucose or $\mathrm{Na}$ glutamate as sole carbon source. The organisms were grown overnight from a small inoculum in medium $63+500 \mu \mathrm{g}$. glucose $/ \mathrm{ml}$. or $500 \mu \mathrm{g}$. Na glutamate $/ \mathrm{ml}$. and ${ }^{59} \mathrm{Fe}$. In the morning the organisms were collected on a membrane filter and resuspended to an optical density (Zeiss spectrophotometer; see Maaløe \& Richmond, 1961) of about 0.05 in fresh medium of the same composition. Samples taken at intervals into a final concentration of $5 \%(w / v)$ trichloroacetic acid (TCA) solution were filtered and radioactivity determined on the filters. It was found (Fig. 1), that, on a differential basis, the uptake of ${ }^{59} \mathrm{Fe}$ by glutamate-grown organisms was about $1 \cdot 8$ times the rate of uptake by glucosegrown bacteria. As the specific activity of the ${ }^{59} \mathrm{Fe}$ added in the experiment was 
known, the iron content of glucose and glutamate grown bacteria could be calculated as 0.02 and $0.036 \%$, by weight. Assuming an approximate value of $0.5 \%$ for the iron content of cytochromes (see Paul, 1951; Tissières, 1956; Takahashi, Titani \& Minakami, 1959; Horio et al. 1960), these figures correspond to a total cytochrome content of 4 and $\mathbf{7 \cdot 2} \%$, respectively. Extraction of the soluble cytochrome components, however, showed that glutamate from bacteria contained about $0.8 \%$ of their dry weight in this form, whereas no significant quantity of soluble cytochrome

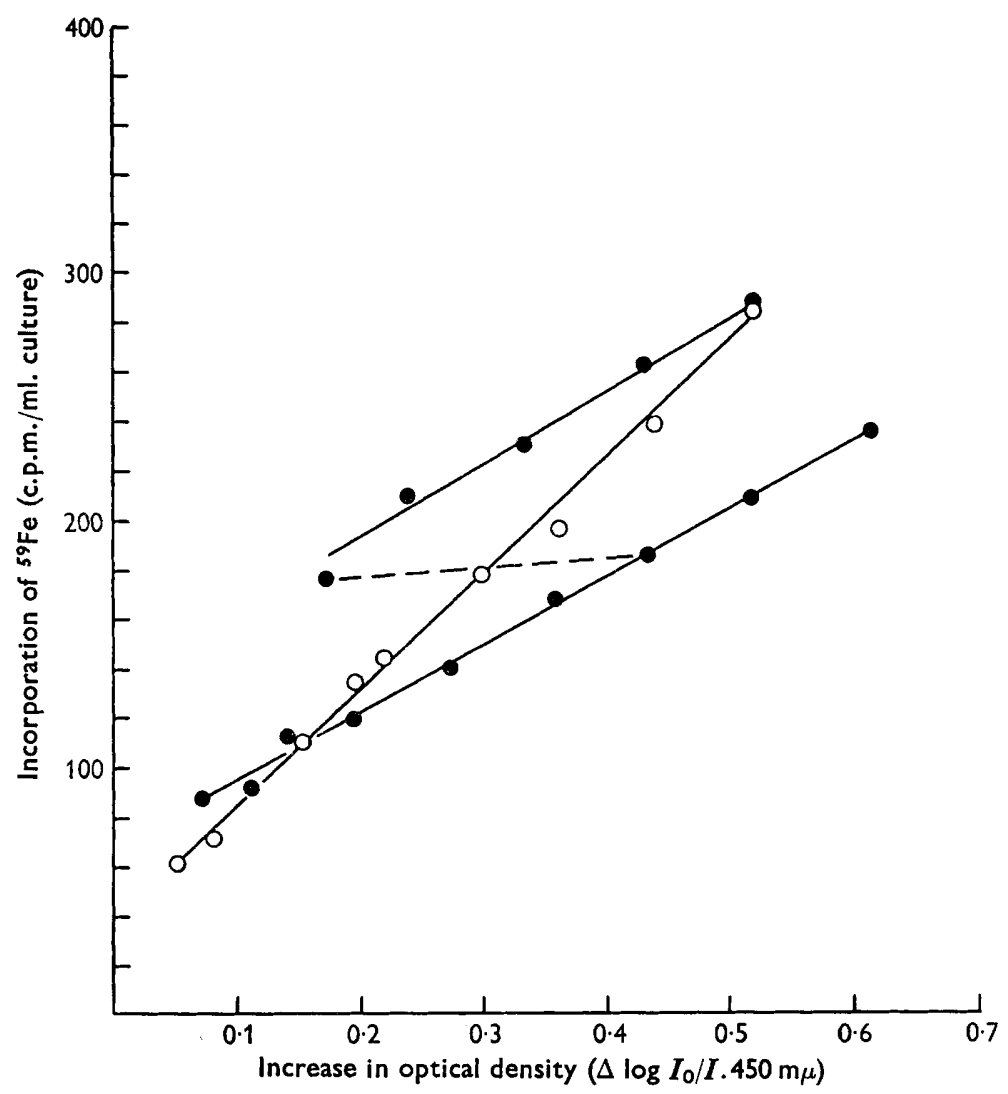

Fig. 1. Incorporation of ${ }^{69} \mathrm{Fe}$ into Salmonella typhimurium growing in medium 63 containing ${ }^{59} \mathrm{Fe}(3,650$ c.p.m. $/ \mu \mathrm{g}$. Fe) and either $500 \mu \mathrm{g}$. Na glutamate $/ \mathrm{ml}$. (O), or $500 \mu \mathrm{g}$. glucose $/ \mathrm{ml}$. (๑). At optical density $=0.435$, half the glucose culture was diluted to an optical density $=0.155$ with fresh medium 63 + glucose and ${ }^{59} \mathrm{Fe}$ at the same specific radioactivity as the original medium (see dashed line).

was detected in extracts of glucose-grown bacteria. It seems possible, therefore, that the total cytochrome content of glucose-grown bacteria might be much lower than suggested by the radioactive iron incorporation experiments, where some at least of the iron uptake might be due to synthesis of other iron-containing proteins such as catalase. 


\section{Transfer of bacteria from one growth medium to another}

The use of the membrane filter technique allowed the transfer of organisms growing in the presence of one carbon source to another medium within 2 min. and with a carry over of less than $1 / 10^{5}$. This technique was, therefore, used to study the effect of transferring organisms which were growing exponentially on a compound from one class to a medium containing another compound of the same class, or to a compound of the other class. Fig. 2 shows a typical example. Organisms growing exponentially in medium $63+500 \mu \mathrm{g}$. glutamic acid $/ \mathrm{ml}$. were filtered and resuspended

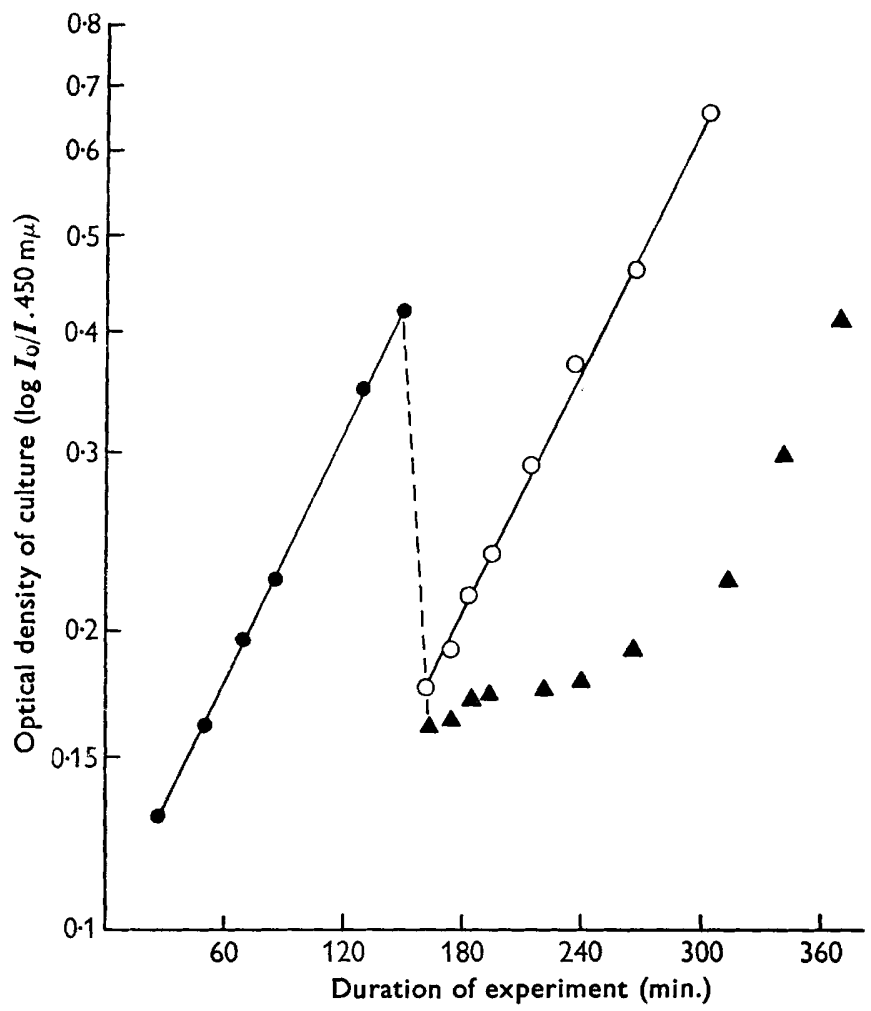

Fig. 2. Growth curves obtained on shifting Salmonella typhimurium from medium 63+ $\mathrm{Na}$ glutamate to similar medium + glucose. A culture growing exponentially in medium $63+500 \mu \mathrm{g}$. Na glutamate $/ \mathrm{ml}$. (O) was filtered and the total yield of organisms divided between two culture flasks containing medium $63+500 \mu \mathrm{g}$. Na glutamate $/ \mathrm{ml}$. (O), or $500 \mu$ g. glucose $/$ ml. (A).

in medium $63+500 \mu \mathrm{g}$. succinate $/ \mathrm{ml}$. or medium $63+500 \mu \mathrm{g}$. glucose $/ \mathrm{ml}$. Transfer to succinate led to an immediate resumption in growth at the full rate characteristic of succinate. The organisms transferred to glucose did not grow appreciably for about $2 \mathrm{hr}$., and thereafter the final rate for glucose-grown bacteria was not reached for about 4 generations. Control experiments showed that contamination of the glucose culture with traces of glycerol from the filters did not affect the length of the lag. Table 2 summarizes similar shifts carried out with other combinations of substrates. The basic pattern that is established is that organisms transfer smoothly to substrates of their own class, but not to substrates of the other class. Certain 
exceptions are evident (see cases marked by asterisk in Table 2). Bacteria grown on substrates related to the Krebs cycle did not grow immediately when transferred to proline or histidine as sole carbon source, although they are members of the same class. Histidine-grown bacteria did not transfer smoothly to proline, nor prolinegrown bacteria to histidine. Since growth on proline or histidine requires the presence of the relevant degrading enzymes which are not present in glutamategrown bacteria (Maaløe \& Richmond, 1961; Richmond, unpublished observations), the lag occurring with these transfers almost certainly represented the time taken

Table 2. Effect of shifting cultures of Salmonella typhimurium from medium 63 containing one compound as sole carbon source to another

\begin{tabular}{|c|c|c|c|c|c|c|}
\hline & & $\begin{array}{l}\text { bon source } \\
\text { e-like class) }\end{array}$ & & $\begin{aligned} \text { Ist } \\
\text { (glut }\end{aligned}$ & $\begin{array}{l}\text { ten source } \\
\text { tike class) }\end{array}$ & \\
\hline & $\begin{array}{l}\text { 1st carbon } \\
\text { source }\end{array}$ & $\begin{array}{l}\text { 2nd carbon } \\
\text { source }\end{array}$ & Lag & $\begin{array}{l}\text { 1st carbon } \\
\text { source }\end{array}$ & $\begin{array}{l}\text { 2nd carbon } \\
\text { source }\end{array}$ & Lag \\
\hline $\begin{array}{l}\text { 2nd carbon source } \\
\text { (glucose-like class) }\end{array}$ & $\begin{array}{l}\text { glucose } \\
\text { glycerol } \\
\text { glucose } \\
\text { mannose } \\
\text { fructose } \\
\text { arabinose } \\
\text { glucose }\end{array}$ & $\begin{array}{l}\text { mannose } \\
\text { glucose } \\
\text { glycerol } \\
\text { glucose } \\
\text { glucose } \\
\text { glucose } \\
\text { arabinose }\end{array}$ & $\begin{array}{l}- \\
+^{*} \\
- \\
- \\
t^{*}\end{array}$ & $\begin{array}{l}\text { glutamate } \\
\text { proline } \\
\text { histidine } \\
\text { proline } \\
\text { glutamate } \\
\text { malate } \\
\text { a-ketoglutarate }\end{array}$ & $\begin{array}{l}\text { succinate } \\
\text { succinate } \\
\alpha \text {-ketoglutarate } \\
\text { pyruvate } \\
\text { mannose } \\
\text { glucose } \\
\text { glucose }\end{array}$ & $\begin{array}{l}- \\
- \\
- \\
+ \\
+ \\
+\end{array}$ \\
\hline $\begin{array}{l}\text { 2nd carbon source } \\
\text { (glutamate-like class) }\end{array}$ & $\begin{array}{l}\text { glucose } \\
\text { glucose } \\
\text { glucose } \\
\text { glucose } \\
\text { glutamate } \\
\text { glutamate } \\
\text { proline } \\
\text { histidine }\end{array}$ & $\begin{array}{l}\text { succinate } \\
\text { glutamate } \\
\text { histidine } \\
\text { alanine } \\
\text { proline } \\
\text { histidine } \\
\text { glutamate } \\
\text { glutamate }\end{array}$ & $\begin{array}{l}+ \\
+ \\
+ \\
+ \\
+ \\
+ \\
-\end{array}$ & $\begin{array}{l}\text { histidine } \\
\text { proline } \\
\text { malate } \\
\text { malate } \\
\alpha \text {-ketoglutarate } \\
\text { glutamate } \\
\text { proline } \\
\text { histidine } \\
\text { histidine } \\
\text { proline } \\
\text { glutamate } \\
\text { succinate }\end{array}$ & $\begin{array}{l}\text { proline } \\
\text { histidine } \\
\text { succinate } \\
\text { glutamate } \\
\text { malate } \\
\text { proline } \\
\text { glutamate } \\
\text { glutamate } \\
\text { glucose } \\
\text { glucose } \\
\text { glucose } \\
\text { glucose }\end{array}$ & $\begin{array}{l}+* \\
+ \\
- \\
- \\
+ \\
- \\
- \\
+ \\
+ \\
+ \\
+\end{array}$ \\
\hline
\end{tabular}

* Cases where a lag occurs after shift experiments involving two carbon sources from the same class. These are probably due to the time required to form specific degrading enzymes (see text).

for the organisms to synthesize sufficient of the substrate-degrading enzymes to support growth. In the glucose class, a similar lag was found on transfer to glycerol or arabinose, but not in the reverse direction. This was probably due to the need to make the arabinose- or glycerol-degrading enzymes.

\section{Effect of addition of glucose to cultures growing in medium $63+\mathrm{L}$-glutamate}

Glucose is known to repress the formation of a number of enzymes (see Magasanik, 1957). It was therefore of interest to see whether addition of glucose to a culture growing exponentially in medium $63+$ glutamate would result in any change in the colour of the organisms. A culture was grown in medium $63+500 \mu \mathrm{g}$. Na glutamate/ ml., and after about three generations of exponential growth the culture was divided into two parts and sufficient solid glucose added to one part to bring the final concentration to $500 \mu \mathrm{g}$. glucose $/ \mathrm{ml}$. Samples (containing about $\mathbf{2} \times 10^{10}$ bacteria), taken at intervals from both cultures after the addition of glucose, were filtered and 


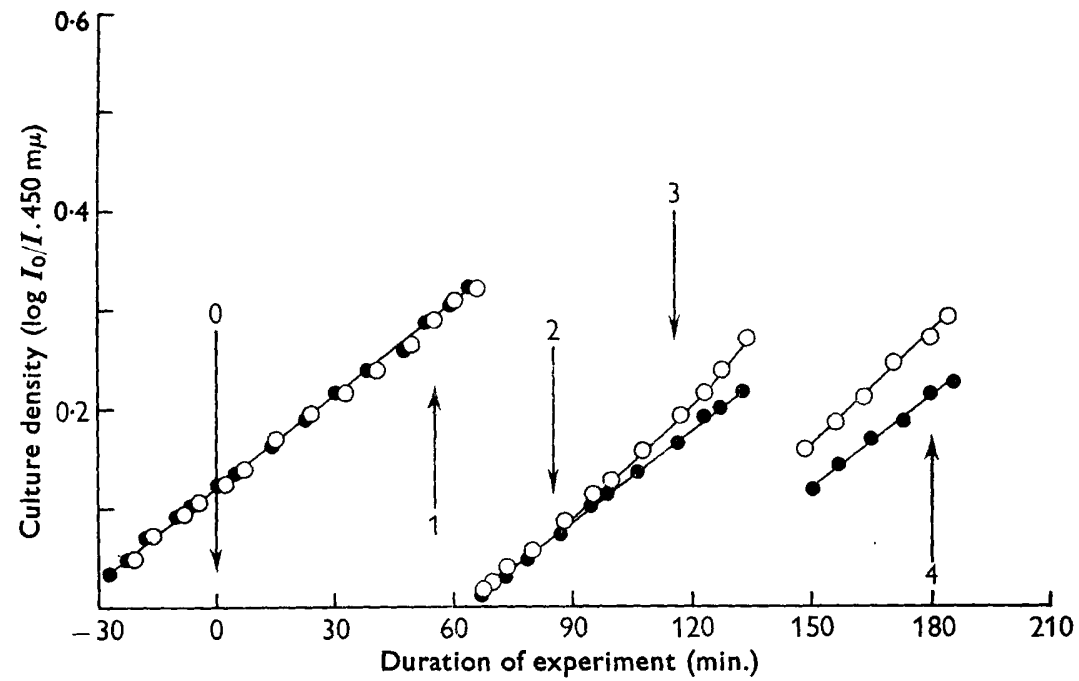

Fig. 3. The effect of addition of glucose on the growth rate (this figure) and colour (Fig. 4) of a culture of Salmonella typhimurium growing exponentially in medium containing glutamate. Cultures growing in medium $63+500 \mu \mathrm{g}$. Na glutamate $/ \mathrm{ml}$. (O) and in medium $63+500 \mu \mathrm{g}$. Na glutamate $+500 \mu \mathrm{g}$. glucose $/ \mathrm{ml}$. (O). Glucose added at $t=0$. The cultures were diluted with fresh media as appropriate at $t=67$ and $t=133$. Samples were taken for colour determinations (see Fig. 4) at $t=0,55,85,115$ and 180 (see arrows).

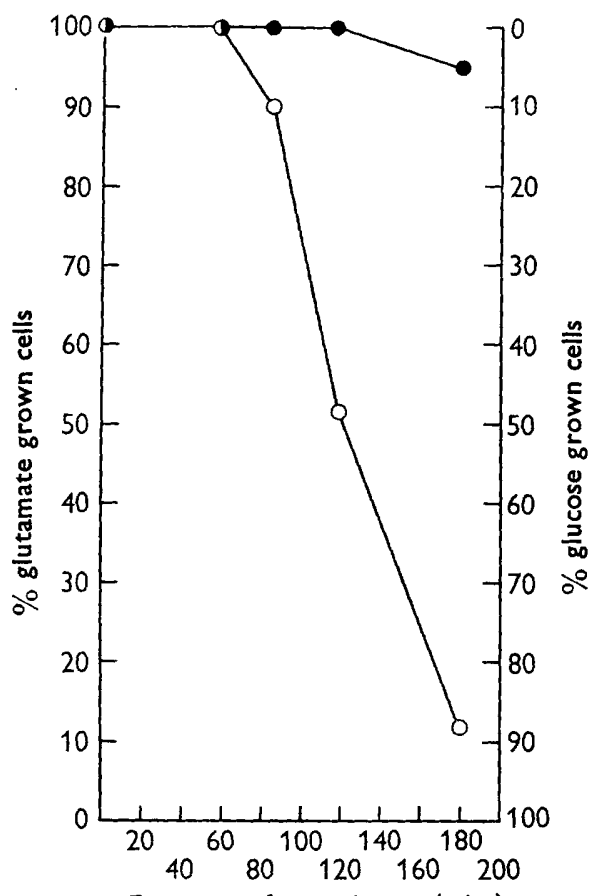

Duration of experiment (min.)

Fig. 4. Samples containing approximately $2 \times 10^{10}$ organisms were taken at the times indicated in Fig. 3 and filtered as described in the methods section. The points plotted represent the 'colours' of the filters from the average of six different settings achieved by uninitiated people. Organisms grown in glutamate alone (๑); organisms grown in glutamate + glucose $(O)$. 
the colour of the filtered bacteria compared with a standard curve of filtered bacteria prepared as described in Methods. After the cultures had doubled in optical density from the point of addition of glucose, they were adjusted to the original optical density by the addition of medium 63 containing either $500 \mu \mathrm{g}$. Na glutamate $/ \mathrm{ml}$. or $500 \mu \mathrm{g}$. Na glutamate $/ \mathrm{ml} .+500 \mu \mathrm{g}$. glucose $/ \mathrm{ml}$., as appropriate. Sampling was continued, and after a further doubling of the optical density, the cultures were once more diluted to the original optical density. The results of this experiment are shown in Fig. 3. Bacteria growing in $\mathrm{Na}$ glutamate continued to grow at the final rate for that medium, and the organisms remained pink throughout the experiment.

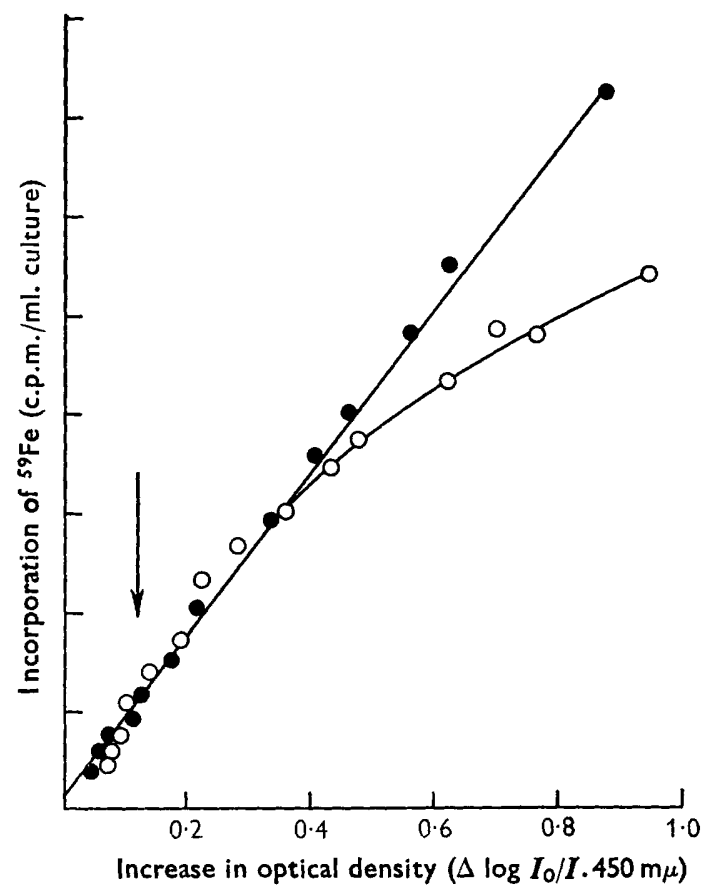

Fig. 5. The effect of addition of glucose on the incorporation of ${ }^{50} \mathrm{Fe}$ into Salmonella typhimurium growing in medium $63+\mathrm{Na}$ glutamatc. Glucose added at optical density $=$ $0 \cdot 12$ (see arrow). Culture growing in medium $63+500 \mu \mathrm{g}$. glutamate $/ \mathrm{ml}$. (e) or medium $63+500 \mu \mathrm{g}$. glutamate $/ \mathrm{ml}$. $+500 \mu \mathrm{g}$. glucose $/ \mathrm{ml}$. (O).

Addition of glucose led to an increase in the growth rate, but this was only detectable about one generation after the glucose was added. Subsequently the growth rate on the glucose + glutamate mixture continued to increase until about 2-3 generations after the addition of the glucose (see Fig. 3). No change of colour from that characteristic of glutamate-grown bacteria was detected for about one generation. Thereafter, the organisms gradually became paler (Fig. 4). When the effect of addition of glucose on the incorporation of ${ }^{59} \mathrm{Fe}$ into cultures growing on medium 63 containing ${ }^{59} \mathrm{Fe}$ and $\mathrm{L}$-glutamate $(500 \mu \mathrm{g}$. $/ \mathrm{ml}$.) was followed in a similar way (Fig. 5), it was found that the differential rate of incorporation was not affected for about one generation; thereafter it decreased to a rate characteristic of growth in medium $63+$ glucose as sole carbon source (see Fig. 5). It seems, therefore, that addition of glucose to a culture growing in medium $63+$ glutamate lead to a shift to the 
glucose-grown state even when glutamate remained in the medium; but the onset of the shift could not be detected in the growth curve or the uptake of ${ }^{59} \mathrm{Fe}$ for about one generation. This is probably related to the fact that the organisms grown on glutamate as sole carbon source did not seem to be able to metabolize glucose immediately (see Table 2 and Fig. 2 ).

The following experiment further substantiates this point as well as showing that glucose had a similar effect in cultures growing in medium $63+$ proline. A culture growing exponentially in medium $63+500 \mu \mathrm{g}$. proline $/ \mathrm{ml}$. was filtered and the organisms resuspended in three batches of medium 63 with the following additions

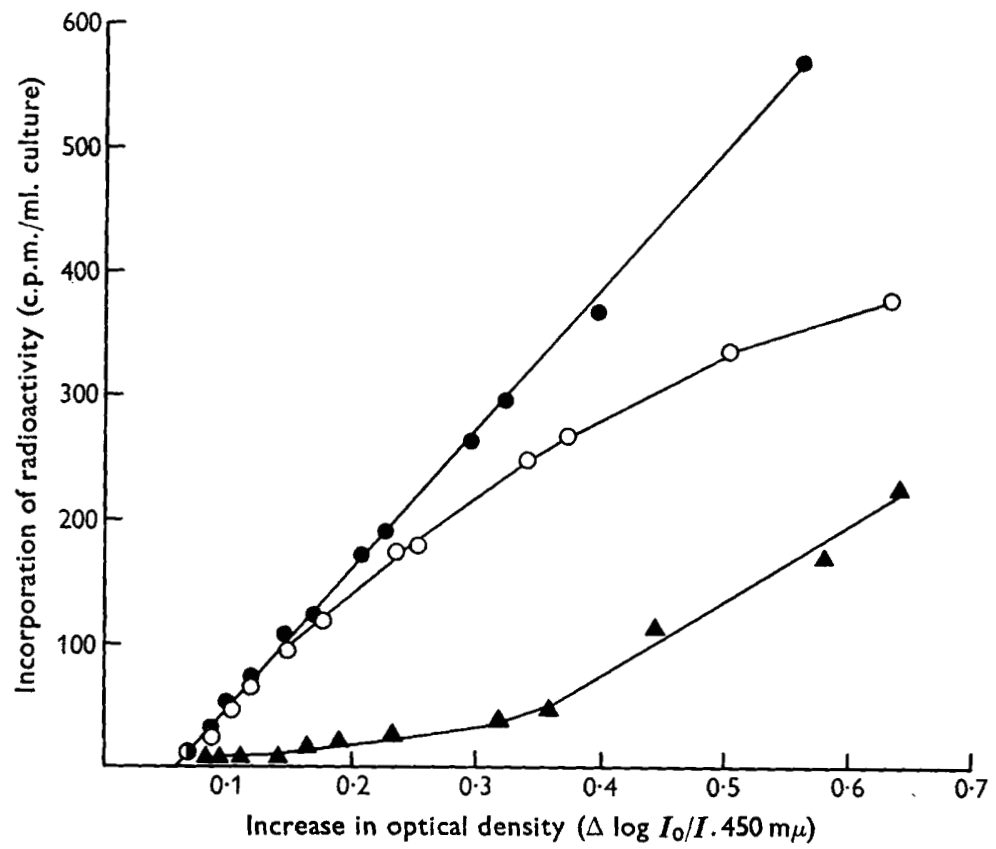

Fig. 6. The effect of addition of glucose to a culture of Salmonella typhimurium growing exponentially in medium $63+$ proline. A culture growing exponentially in media $63+$ proline was filtered and the organisms resuspended in media of the following composition: (1) medium $63+500 \mu \mathrm{g} .{ }^{14} \mathrm{C}$-proline $/ \mathrm{ml}$. (O); (2) medium $63+500 \mu \mathrm{g} .{ }^{14} \mathrm{C}$ proline $/ \mathrm{ml} .+$ $500 \mu$ g. ${ }^{12} \mathrm{C}$-glucose $/ \mathrm{ml}$. (O); (3) medium $63+500 \mu \mathrm{g} .{ }^{12} \mathrm{C}$-proline $/ \mathrm{ml} .+500 \mu \mathrm{g} .{ }^{14} \mathrm{C}$-glucose/ ml. (A). Specific radioactivity : proline : 11.5 c.p.m. $/ \mu \mathrm{g}$; glucose : $8 \cdot 8$ c.p.m. $/ \mu \mathrm{g}$.

(all $500 \mu \mathrm{g} . / \mathrm{ml}$.): (1) ${ }^{14} \mathrm{C}$ proline; (2) ${ }^{14} \mathrm{C}$ proline $+{ }^{12} \mathrm{C}$ glucose; $(3){ }^{12} \mathrm{C}$ proline $+{ }^{14} \mathrm{C}$ glucose. Samples taken at intervals from each culture were precipitated with an equal volume of cold $10 \%(\mathrm{w} / \mathrm{v}) \mathrm{TCA}$ solution and the incorporation of radioactivity followed by the filter technique (Fig. 6). Culture (1) gave the final differential rate of ${ }^{14} \mathrm{C}$ proline incorporation for proline-grown bacteria. Culture (2) showed that the addition of ${ }^{12} \mathrm{C}$ glucose to cultures growing in proline lead to a decrease in the differential rate of proline incorporation, but that little effect on this rate was detectable for at least one generation after the addition of glucose. Culture (3) confirmed that the differential rate of incorporation of glucose by proline-grown bacteria was very low for about one to two generations after the addition of glucose, but that the rate slowly increased as the utilization of proline decreased. Since glucose had little effect on the flow of radioactivity from ${ }^{14} \mathrm{C}$ proline to the cell for 
about one generation, it follows that glucose did not cause immediate complete regression of the formation of the proline-degrading enzymes. However, continued incubation in media containing glucose decreased the ability of the organisms to utilize proline to about $5 \%$ of the original rate after about five generations. This is very similar to the effect of glucose on the behaviour of cultures growing in glutamate (see abovc), but markedly different from the effect of glutamate on bacteria growing in medium $63+$ proline (Maaløe \& Richmond, 1961).

\section{Transfer of Escherichia coli between media containing single compounds as sole carbon sources}

Since lags occurred after the transfer of Salmonella typhimurium from media containing substrates related to glucose to substrates related to the Krebs cycle, it was of interest to see whether this was a phenomenon found in another

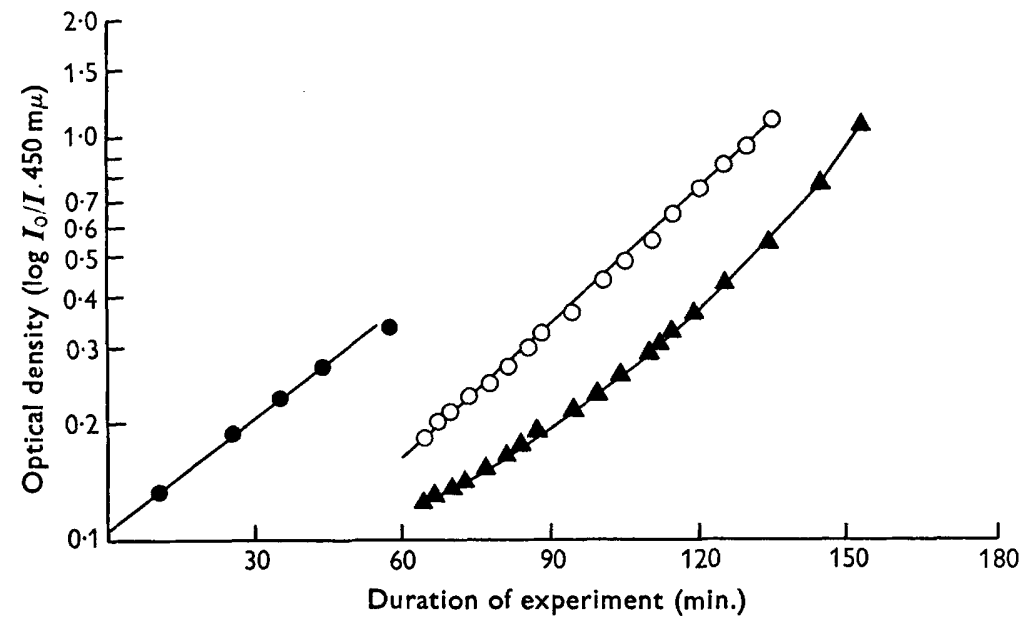

Fig. 7. Growth curves obtained by shifting Escherichia coli (ML30) from medium 63+ Na malate $(500 \mu \mathrm{g} . / \mathrm{ml}$.) (O) to medium 63 containing Na succinate $(500 \mu \mathrm{g} . / \mathrm{ml}).(\mathrm{O})$, or glucose $(500 \mu \mathrm{g} . / \mathrm{ml}$.) $(\Delta)$. Culture filtered and washed at $t=123 \mathrm{~min}$.

organism capable of rapid growth on the simple defined medium 63. To test this, a culture of Escherichia coli (ML 30) was grown up overnight in medium $63+$ $500 \mu \mathrm{g}$. Na malate $/ \mathrm{ml}$. In the morning the culture was transferred to fresh medium of the same composition until growth was exponential. After about four generations under these conditions the culture was filtered and divided between two portions of medium 63 containing $500 \mu \mathrm{g}$. glucose and $500 \mu \mathrm{g}$. Na succinate $/ \mathrm{ml}$, respectively.

The subsequent growth of these cultures (Fig. 7) was followed for about $3 \mathrm{hr}$. The culture transferred to succinate grew immediately at the full rate characteristic of succinate. The culture transferred to glucose grew immediately but with a slowly increasing differential rate. It took at least two generations for the growth rate to reach the full rate characteristic of Escherichia coli growing in medium $63+$ glucose. Other transfers were carried out, between succinate $\rightarrow$ glucose, glutamate $\rightarrow$ glucose and glucose $\rightarrow$ succinate. In all cases the organisms took up to two generations before they reached the rates characteristic of the second substrates, whereas transfers between succinate $\rightarrow$ malate, succinate $\rightarrow$ fumarate and succinate $\rightarrow$ 
alanine led to immediate growth at the full rate in the new medium. It follows that Escherichia coli shows the same general response as Salmonella typhimurium to these changes in growth medium, but that the effects are much less dramatic.

\section{DISCUSSION}

Growth of this strain of Salmonella typhimurium with various substrates as sole carbon source led to the formation of organisms of two main types. Bacteria grown on compounds related metabolically to glucose were white and had a relatively low cytochrome and inorganic iron content. On the other hand, bacteria grown with substrates related to the Krebs cycle were pink, had a relatively high cytochrome and iron content, and showed the presence of a soluble cytochrome component (C-type-551: Richmond \& Kjeldgaard, 1961) which was either absent, or present in very low concentrations in the glucose-grown bacteria. Fluctuations in the cytochrome content of micro-organisms have been reported by a number of workers (see review by Smith, 1954), but were usually found under conditions in which the oxygen tension in the growth medium was varied (e.g. Moss, 1952; Schaeffer, 1952 $a, b$; Lenhof \& Kaplan, 1953; Chaix \& Petit, 1956, 1957; Rosenberger \& Kogut, 1958; Heyman-Blanchet \& Chaix, 1959). Changes in growth medium have been reported to alter the cytochrome content of cells, but these experiments were usually carried out in complex media in which it was difficult to assess the results (e.g. Keilin, 1933; Gary \& Bard, 1952).

It is now generally recognized that the Krebs cycle is one of the main pathways whereby bacteria obtain the energy necessary for growth (see Krebs \& Kornberg, 1957). However, it is not the only one, since Roberts et al. (1957) showed that when Escherichia coli grew on glucose only $30 \%$ of the total amount of $\mathrm{CO}_{2}$ evolved by the organism came from the Krebs cycle and that, under these conditions, the cycle plays a predominantly synthetic role. As most of the $\mathrm{CO}_{2}$ evolved came from the $C_{1}$ position in glucose, the oxidation of glucose in these organisms probably occurred via the glucose shunt pathway (see Krebs \& Kornberg, 1957). Under these circumstances, therefore, it is tempting to think of the two classes of organisms encountered in the present work as characterized fundamentally by the methods in which they derive their energy. Thus organisms of the pink (glutamate-grown) group could derive their energy from the operation of the Krebs cycle and the pink colour is due to a high content of cytochrome, which is known to be associated with some enzymes of the Krebs cycle. On the other hand, the white (glucose-grown) cells could derive their energy from the pathways of glucose degradation: either glycolysis, the glucose shunt pathway or some unidentified pathway. The experiments in which bacteria were transferred from one media to another show that, in general, organisms grown on a compound related to the Krebs cycle did not grow immediately when transferred to media containing a compound from the glucose group as sole carbon source, and vice versa. This was probably because the organisms did not contain the enzymes necessary for growth in the new medium and the lag represented the time taken to synthesize them. Since the system to be synthesized is to be the main energy producing system of the organisms in their new environment, the energy for making these enzymes must, initially, have to come from incidental reactions. This, presumably, accentuates the length of the lag observed, which 
may be up to six generations before the full final growth rate in the new medium is attained.

Since addition of glucose to cultures growing in glutamate led to a switch to the 'glucose-like' state and the loss of the ability to utilize glutamate, the glucose-like state must predominate over the glutamate-like. This is a situation analogous to the 'glucose-effect' found during the synthesis of a number of bacterial enzymes (Magasanik, 1957). The finding that, in the present experiments with Salmonella typhimurium, the effect was not instantaneous, is presumably due to the fact that glucose was not immediately metabolized when it was added to cultures growing with glutamate or proline as sole carbon source.

The experiments carried out with Escherichia coli suggest that a similar situation may occur with these organisms, but the results are not nearly so clear cut. One possible interpretation of these results is that many bacteria can organize their enzymic make-up in a number of ways centred about different methods of deriving energy for growth, and that in some organisms the balance between the various pathways is closer than in others. In the case of the strain of Escherichia coli studied here, both the Krebs cycle and the glucose-degrading systems seem to be present in the same cell at the same time and subject only to minor fluctuations. With our strain of Salmonella typhimurium, the organism seems to be much more committed to one or the other type of metabolism and the concomitant enzymic make-up.

This work was supported by a Fellowship awarded to one of us (M.H.R.) and a grant in aid given to the University Institute of Microbiology by the CIBA Fellowship Trust.

\section{REFERENCES}

Chatx, P. \& Petrt, J. F. (1956). Étude de différents spectres cytochromiques de Bacillus subtilis. Biochim. biophys. Acta, 22, 66.

Chaix, P. \& Petrt, J. F. (1957). Influence de taux de croissance sur la constitution du spectre haematinique du Bacillus subtilis. Biochim. biophys. Acta, 25, 481.

GARY, N. D. \& BARD, R. C. (1952). Effect of nutrition on growth and metabolism of B. subtilis. J. Bact. 64, 501.

Heyman-Blanchet, T. \& Chaix, P. (1959). Variations du spectre cytochromique de la levure cultivée en anaérobiose en fonction de ses phases de croissance. Biochim. biophys. Acta, 35, 85.

Horio, T., Higashi, T., Sasagawa, M., Kusai, K., Nakai, M. \& Okunuki, K. (1960). Preparation of crystalline Pseudomonas cytochrome C-551 and its general properties. Biochem. J. 77, 194.

Keilin, D. (1933). Supposed direct spectroscopic observation of the oxygen transporting ferment. Nature, Lond. 132, 783.

Krebs, H. A. \& Kornberg, H. L. (1957). Energy transformations in living matter: a survey. Ergebn. Physiol. 49, 212.

Lenhof, H. W. \& Kaplan, N. O. (1953). A cytochrome peroxidase from Pseudomonas fuorescens. Nature, Lond. 172, 730.

MaAløe, O. \& Richmond, M. H. (1961). The rate of growth of Salmonella typhimurium with proline or glutamate as sole C source. J. gen. Microbiol. 27, 269.

Magasanik, B. (1957). Nutrition of bacteria and fungi. Annu. Rev. Microbiol. 11, 221.

Moss, F. (1952). The influence of oxygen tension on respiration and cytochrome $\mathrm{a}_{2}$ formation in Escherichia coli. Aust. J. exp. Biol. med. Sci. 30, 531.

Paul, K.-G. (1951). In The Enzymes, II, part I, p. 357. Ed. J. B. Sumner \& K. E. Myrbäck. New York: Academic Press. 
Richmond, M. H. \& KJeldgaArd, N. O. (1961). Cytochrome C-551 from Salmonella typhimurium. Acta chem. scand. 15, 226.

Roberts, R. B., Abelson, P. H., Cowie, D. B., Bolton, E. T. \& Britten, R. J. (1957). Studies of Biosynthesis in Escherichia coli. Carneg. Inst. Wash. Publ. No. 607. Second Printing.

Rosenberger, R. F. \& Kogut, M. (1958). The influence of growth rate and aeration on the respiration and cytochrome systems of a fluorescent pseudomonad grown in continuous culture. J. gen. Microbiol. 19, 228.

SchaffFer, P. (1952a). Disparition partielle des cytochromes par cultures anaérobies chez certaines bactéries aérobes facultatives. Biochim. biophys. Acta, 9, 261.

Schatffer, P. (1952b). Excrétion de porphyrines par cultures anaérobies chez certaines bactéries aérobies facultatives. Biochim. biophys. Acta, 9, 362.

Smitr, L. (1954). Bacterial cytochromes. Bact. Rev. 18, 106.

Takahashi, K., Trtani, K. \& Minakami, S. (1959). The structure of cytochrome C. J. Biochem. Tokyo, 46, 1323.

Tissières, A. (1956). Purification, some properties and the specific biological activity of cytochromes $C_{4}$ and $C_{5}$ from Azotobacter vinelandii. Biochem. J. 64, 582. 